\title{
New Occupational Exposures with Respiratory Effects
}

\author{
Subhabrata Moitra', PhD, FRSPH and Prasun Haldar ${ }^{2}, \mathrm{PhD}$
}

${ }^{1}$ Alberta Respiratory Centre, Department of Medicine, University of Alberta, Edmonton, Canada; ${ }^{2}$ Department of Biological Sciences, Midnapore City College, Midnapore, India

\section{ABSTRACT}

Occupational exposure is one of the major risk factors for lung diseases globally. Although the aetiology and the course of major occupational lung diseases are well understood, the nature of lung diseases caused by new agents is still not well evaluated. The rise of interstitial and malignant lung diseases due to occupational exposures has caught global attention because either the causal agents are novel and the mode of action is poorly understood, or classical exposures have reappeared in a newer way, or the control measures are not implemented properly. With the introduction of new and innovative technologies, new agents such as indium compounds, diketones, nanomaterials, and physical processes such as hydraulic fracking are being introduced with substantially high deliberating effects on the workers' health. In this review, we summarise some new occupational exposures contributing to respiratory diseases and provide some recommendations for reducing the burden of occupational lung diseases. (BRN Rev. 2021;7(1):27-46)

Corresponding author: Subhabrata Moitra, moitra@ualberta.ca

Key words: Lung diseases. Occupational exposure. Respiratory health. Workplace hazard. 


\section{INTRODUCTION}

Occupational lung diseases have been a global issue, although the magnitude of this problem in different parts of the world is difficult to estimate with accuracy. However, with the rapidly increasing global population and demand for consumer goods, more and more new materials are being invented and introduced in various occupations, most of the time without perceiving the health risk of those materials. According to an estimate of the International Labour Organization (ILO), 2 million people die each year from occupational diseases or workplace accidents, and nearly $30 \%$ of those occupational diseases are due to lung ailments, particularly cancer and obstructive and interstitial diseases ${ }^{1}$. Occupational exposures are still an important cause of mortality and morbidity worldwide ${ }^{2}$.

Despite amendments of various safety measures in the workplaces and workers' compensation policies, occupational exposures are still persistent in the developed countries, while such regulations hardly exist in industrially developing countries. One of the most disheartening examples of unregulated industrial hazards is the Bhopal gas tragedy caused by the leakage of a dangerous industrial chemical, methyl isocyanate (MIC), that took the life of more than 16,000 people until now and affected over half a million ${ }^{3,4}$. It also caused epigenetic defects in the survivors and their future generations, leading to haematopoietic disorders, cancer, and lung diseases ${ }^{5}$.

In today's developing countries, most of the workers are still exposed to hazardous industrial substances. In India, around 11.5 million workers are exposed to silica dust, and there is an additional burden of attendant tuberculosis $^{6}$. In countries like China and South Africa, where mining is a major industry, silicosis is still one of the most prevalent diseases ${ }^{7}$. Recently, an increase in the incidence of occupational lung diseases caused by the new application of long-recognised hazardous substances such as silica has been reported ${ }^{8}$. Mica, the glitters used in cosmetics, paints, electronics, and other appliances, is mined in some developing countries where informal labourers, particularly children, are immensely exposed to this fibrogenic substance. Several reports have described the clinical and pathological features of mica pneumoconiosis ${ }^{9-12}$. It is also evident that the newly administered materials pose a substantial threat for humans. Unfortunately, however, in most developing countries workers' safety and labour acts are non-existent ${ }^{1}$. Multiple reports have been documented in the developed countries in the past two decades addressing new and unique exposures, which have severely impacted the respiratory health of hundreds of thousands of workers, such as insulating materials other than asbestos ${ }^{13}$, dust from the world trade centre (WTC) collapse ${ }^{14}$, among others. In this review, we summarised recent reports of occupational lung diseases caused by newly recognised occupational hazards and some old exposures in new forms (Fig. 1).

\section{SILICA: A CLASSIC EXAMPLE OF AN OLD EXPOSURE IN NEW FORMS}

\section{Denim Sandblasting}

Denim jeans have been considered an essential part of the fashion industry for a long time 


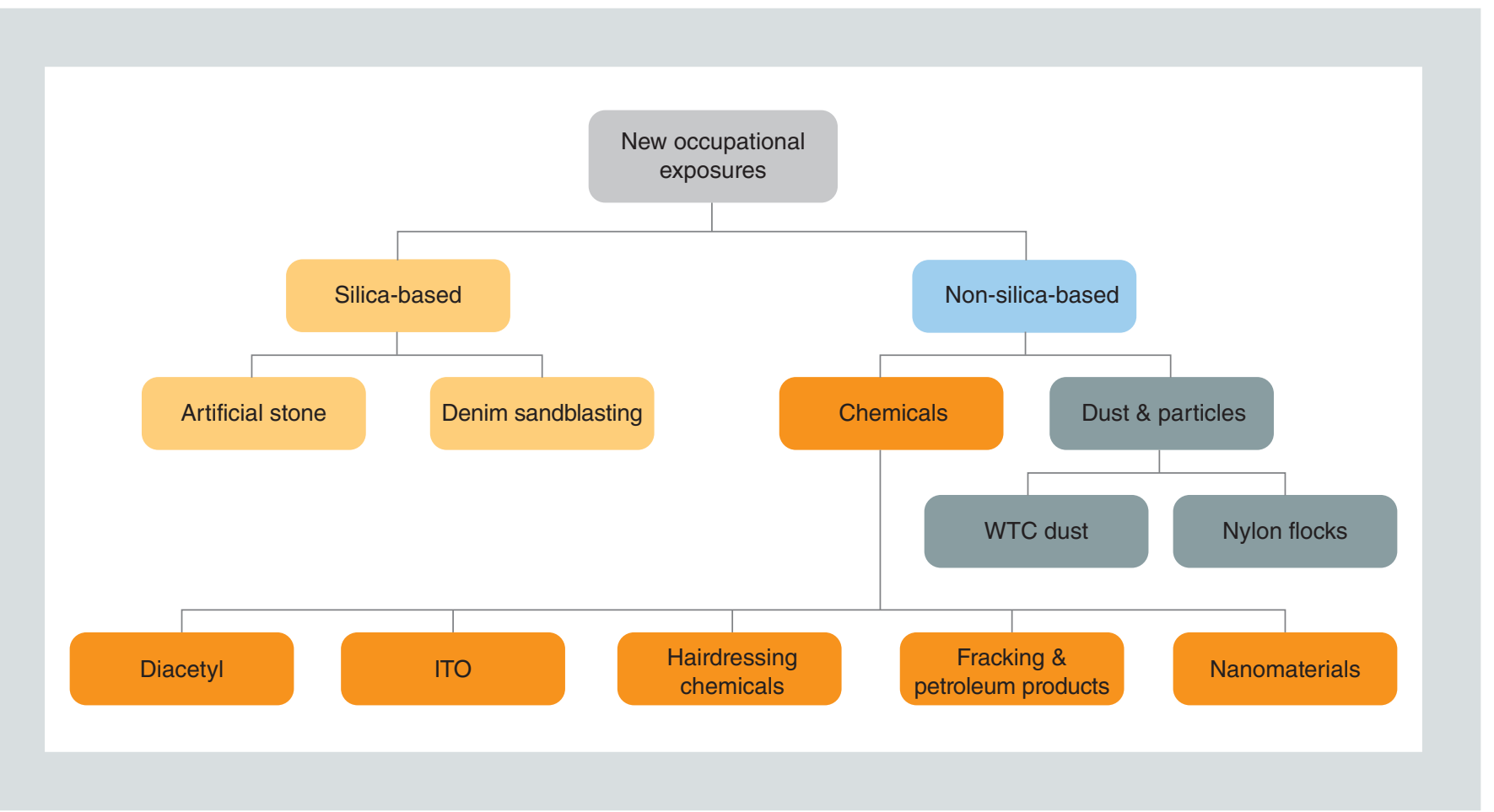

Figure 1. New occupational exposures with potential respiratory effect. In this scheme, we have described some of the newly identified occupational exposures that might be responsible for respiratory health effects.

ITO: indium-tin oxide; WTC: World Trade Centre.

and their faded form is always in high demand. This faded appearance of the jeans can be prepared by sandblasting, a process in which blasting of small particles of sand at high pressure can remove the dark indigo pigment of the jeans and soften/lighten the fabric ${ }^{15}$. Silica dust exposure in such sandblasted jeans production is associated with fatal silicosis and has emerged as a novel workplace haz$\operatorname{ard}^{16-22}$. One study on 157 former denim sandblasters revealed that respiratory symptoms, including dyspnoea and chest pain, were common among them. Radiological evidence of silicosis (ILO score 1.0 or higher) was present in more than $50 \%$ of the subjects with substantial lower lung function. The risk of developing silicosis was correlated with seniority (i.e. working as a foreman), exposure duration, and the number of places of work ${ }^{17}$. A 4-year follow-up study ${ }^{20}$ (145 former sandblasters studied in 2007 among which 83 were reassessed in 2011) reported that silicosis prevalence was increased by about $40 \%$ among the living sandblasters (74 out of 83). A study on 50 denim sandblasters with silicosis found lymphadenopathy (LAP) in 50\% of the patients whereas complicated silicosis, evident from pleural involvement, and presence of progressive massive fibrosis (PMF), were observed in 23 patients ${ }^{23}$. Even short-term exposure to sandblasting and dyeing was associated with decreased breath sounds, bilateral reticulonodular densities, hypoxemia, and restrictive lung disorder among the workers ${ }^{24}$ Death due to PMF among young sandblasters (mean age was 31.5 years) has been reported and suggests a lack of awareness 
about hazardous silica exposure, overexposure to silica dust, unsafe working conditions, and inadequate control of management ${ }^{18}$.

Silicosis due to denim sandblasting is also associated with an altered metabolic and immune function that triggers a positive feedback loop, and the disease progression occurs as a result of altered immune and metabolic function. Progression of silicosis can activate the immune system and oxidative stress via increased neopterin levels and tryptophan degradation; such increased oxidative stress was also associated with the severity of the disease $^{25}$. Patients with silicosis due to denim sandblasting were also reported to have higher serum lactate dehydrogenase that showed a significant correlation with the radiological extent of disease and pulmonary function tests $^{26}$. Autoimmune response may contribute significantly to silicosis development among sandblasters, more specifically, human leukocyte antigen (HLA) is linked with the severity of silica-induced lung disease but not with the progression time of the disease ${ }^{27}$. Co-occurrence of pulmonary tuberculosis and tuberculous meningitis were also observed in denim sandblasters with silicosis ${ }^{28}$.

Lack of awareness, limited controlling measures, and continuously deteriorating health status plausibly influence the anxiety, depression, and the quality of life of patients with silicosis due to denim sandblasting ${ }^{29}$. Therefore, careful monitoring of exposure, creating substantial awareness among the workers, and finding an alternative way of fading denim are the need of the hour. Personal protective equipment and better treatment options should also be provided to the sandblasting workers to delay or reverse the progression of the disease ${ }^{21}$. Furthermore, chemical processes may be an alternative way as these are cost-effective and safer than sandblasting ${ }^{22}$.

\section{Artificial stone dust}

Artificial stone (also known as engineered or reconstituted stone and quartz conglomerate) is gaining popularity as an alternative to conventional marble kitchen or bathroom countertops. It contains a very large amount of silica $(\sim 90 \%)$, far more than natural marble $(\sim 3 \%)$, and granites $(\sim 30 \%)^{30}$. This engineered stone is created by mixing crushed rock with resin and moulded into slabs ${ }^{31,32}$. During the cutting of these stone slabs, a very large amount of ultrafine silica is produced that remains in the breathing zone of the workers. Dry cutting of these stones produces much more inhalable particles than wet cutting, thus exposing the workers to a very high degree of fibrogenic compounds ${ }^{30,31}$. Several small-scale stone-cutting workshops, mostly unorganized, evolved in the last two decades in various corners of the world employing workers with no or minimal training and knowledge of handling such hazardous materials. Personal protective devices are rarely used by the workers and often not even provided ${ }^{33}$. Several reports have found an unimaginably high concentration of respirable crystalline silica (RCS) at these workplaces $^{34}$. Another report also found a significantly higher amount of metallic components in the artificial stone dust, which could be one of the main reasons for greater free-radical-induced damage in the lungs ${ }^{35}$. Furthermore, a short-term, very high concentration exposure is thought to be more dangerous than a long-term lower concentration exposure to the same volume of $\mathrm{RCS}^{36}$. Several 
new cases of artificial stone-dust associated silicosis emerged in the past few years, and intriguingly, almost all the incidents were reported in industrially developed countries where workers' safety was put into action long before ${ }^{30-33,37,38 \text {. }}$

In a recent report, Ophir and colleagues (2016) ${ }^{31}$ observed lower pulmonary function with significantly higher neutrophilic inflammation among 68 artificial stone processing workers compared to controls. Furthermore, sputum assay also demonstrated the presence of other minerals such as aluminium, zirconium, and titanium in addition to silica ${ }^{31}$. In a group of 68 Israeli artificial stone processing workers, 29 were diagnosed with silicosis. Analysis of sputum ultrafine particles showed an inverse association with lung function and was positively associated with pro-inflammatory cytokines, interleukin-6 (IL-6), IL-9, and tumour necrosis factor- $\alpha(\mathrm{TNF} \alpha)^{39}$. Case reports citing artificial stone workers requiring lung transplant have also emerged in the past few years ${ }^{40}$.

High-resolution computer-assisted tomography (HRCT) scan is vital in diagnosing silica-associated pulmonary complications, particularly in advanced stages when the disease progression is accelerated. HRCT findings in artificial stone-associated silicosis often differ from the classical signatures found in workers exposed to natural stone dust, with progressive aetiology possibly due to extreme exposure to $\mathrm{RCS}^{41,42}$. While a majority of the workers are screened for the classical symptoms of silicosis, atypical signs such as ground-glass opacity and nodal enlargement are observed more prominently in many other cases indicating the involvement of different pathways in the disease manifestations ${ }^{42}$. Table 1 describes a summary of the typical radiological features observed in artificial stone-associated silicosis (Fig. 2).

\section{OCCUPATIONAL EXPOSURES OF THE 21 ${ }^{\text {ST }}$ CENTURY}

\section{Diacetyl: the flavouring agent}

The quest for diacetyl as an occupational hazardous substance began after 2000 when, for the first time, obliterative bronchiolitis with fixed airway obstruction was observed in eight microwave popcorn workers in the US state of Missouri ${ }^{43}$. It was found that all the workers were exposed to diacetyl (2,3-butanedione), a hydrophilic volatile diketone that was being used in the plant as a flavouring material $^{43}$. A surveillance program conducted jointly by the California Department of Public Health and the California Division of Occupational Safety and Health (Cal/OSHA) investigated workers from twenty flavouring companies and found that $23 \%$ of the workers had spirometric abnormalities while nearly $5 \%$ were diagnosed with airway obstruction. Around $10 \%$ of the workers also had an accelerated decline of forced expiratory volume in one second $\left(\mathrm{FEV}_{1}\right)$, and the rate of decline was higher in workers of the factories that used more than 8001 bs of diacetyl every year ${ }^{44}$. Other studies on food processing workers also observed workers encountering the deleterious effects of diacetyl exposure and clinically important lung diseases, such as obliterative bronchiolitis, obstructive airway disease, and lung function decline in workers ${ }^{45-47}$. Workers in a Dutch chemical plant that produced diacetyl also experienced lung abnormalities that indicated diacetyl exposure as the causative factor $^{48}$ (Fig. 3). A 36-year old non-smoking 
TABLE 1. Summary of HRCT features useful in determining the likelihood of silicosis in artificial stone workers

\begin{tabular}{|c|c|c|}
\hline HRCT feature & $\begin{array}{l}\text { Interpretation (in patients with RCS } \\
\text { exposure) }\end{array}$ & Differential diagnosis \\
\hline Eggshell nodal calcification & Likely to reflect silica exposure & \\
\hline Enlarged mediastinal and hilar nodes & May represent reaction to RCS exposure. & Sarcoidosis \\
\hline Upper zone predominant air trapping & Suggestive of hypersensitivity pneumonitis & Respiratory bronchiolitis \\
\hline $\begin{array}{l}\text { Centrilobular ground-glass nodules, upper zone } \\
\text { predominant }\end{array}$ & Suggestive of acute/accelerated silicosis & $\begin{array}{l}\text { Respiratory bronchiolitis, hypersensitivity } \\
\text { pneumonitis }\end{array}$ \\
\hline $\begin{array}{l}\text { Solid nodules, centrilobular or peripheral, with } \\
\text { upper zone predominance }\end{array}$ & Silicosis (simple or complicated) & Sarcoidosis \\
\hline Nodule coalescence to $>10 \mathrm{~mm}$ & Progressive massive fibrosis & Lung malignancy \\
\hline
\end{tabular}

HRCT: High-resolution computer-assisted tomography; RCS: respirable crystalline silica.

Adapted from Jones CM et al. ${ }^{42}$ with permission from John Wiley \& Sons; (c) 2020 The Royal Australian and New Zealand College of Radiologists.

worker of a potato chips production facility was diagnosed with fixed airflow obstruction and was found to have been highly exposed to diacetyl; despite removing him from the active exposure, his lung function did not return to normal, indicating the irreversible nature of lung damage caused by diacetyl ${ }^{49}$. Another study in a coffee processing facility found airborne concentrations of 14,300 ppb of diacetyl and 13,800 ppb of 2,3-pentanedione, much higher than the recommended exposure limit of the National Institute of Occupational Safety and Health of the United States $(\mathrm{NIOSH})^{50}$. Mechanistic studies have shown that diacetyl and 2,3-pentanedione cause damage to the lungs by necrotising the airway epithelium and altering protein homeostasis ${ }^{51}$. These studies underscore the severe impact of occupational exposure to diacetyl on the lung health of the workers. Although measures have now been taken to minimise the exposure to these chemicals at work, longitudinal health surveillance studies are much needed as diacetyl exposure can also lead to long-term pulmonary effects.

\section{Indium and indium-tin oxide}

The recent emergence of indium lung disease indicates a new type of occupational lung disease caused by an already existing material. Indium oxides $\left(\operatorname{In}_{2} \mathrm{O}_{3}\right)$ have been in usage since the early 1930s and were primarily used in semiconductors, dental alloys, batteries, thinfilm infrared reflectors transparent for visible light, some optical coatings, antistatic coatings, and nuclear reactors. In the 90s, a new conjugate comprising of indium oxide and tin oxide (commonly known as indium tin oxide [ITO]) was produced for a broader industrial usage including plasma and flat-screen displays ${ }^{52,53}$, upscaling the production from 371 tons in 1999 to 1380 tons in $2013^{54}$.

The first case of indium-associated lung injury was found in a worker engaged in wet-surface polishing. The patient was diagnosed with interstitial pneumonitis within three years of employment and died four years after the diagnosis ${ }^{55}$. Reports indicate that serum indium concentration (SIn) is strongly associated with the exposure period and that emphysematous 

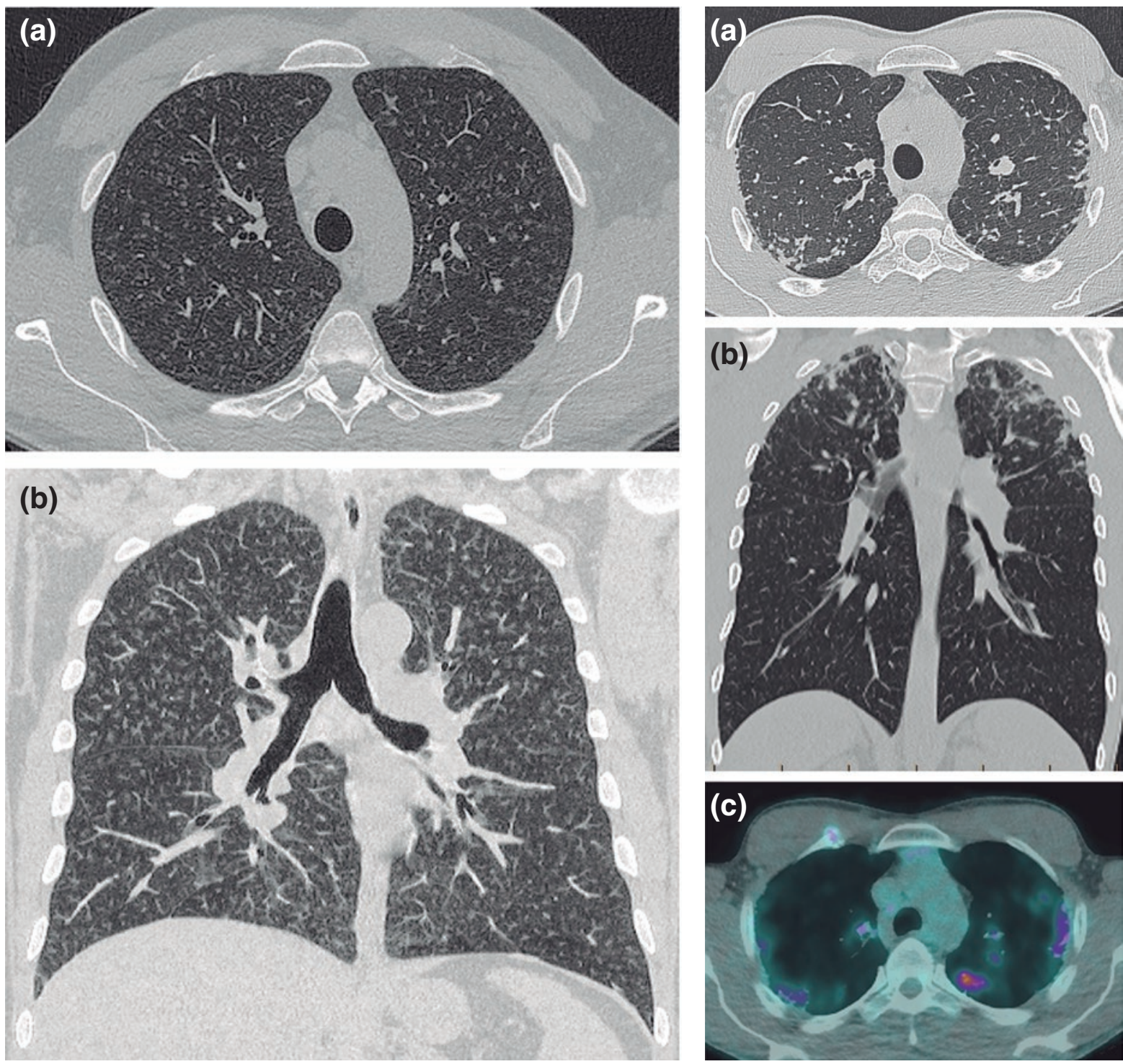

Figure 2. Long-term exposure to artificial stone. (LEFT PANEL) A 49-year-old stonemason, 19 years exposure including to artificial stone, identified through screening. HRCT showed both soft tissue and ground-glass nodules $(\mathbf{a}, \mathbf{b})$ with an upper zone predominance. No nodule coalescence. No change on follow-up HRCT four months later. (RIGHT PANEL) A 34-year-old stonemason, exposed to artificial stone for 10 years. HRCT performed as part of screening demonstrates (a) upper zone predominant centrilobular and peripheral nodules with (b) pseudoplaque formation and PMF. (c) PET imaging demonstrates avidity in the nodes and the PMF conglomerates (reproduced from Jones CM et al. ${ }^{42}$ with permission from John Wiley \& Sons; (C) 2020 The Royal Australian and New Zealand College of Radiologists).

HRCT: High-resolution computer-assisted tomography; PET: Positron emission tomography; PMF: progressive massive fibrosis.

lesions increased progressively in heavily exposed workers, even after cessation of exposure. A non-smoking ex-worker who had stopped working in indium processing was diagnosed with lung cancer 17 years later, which suggested the need for appropriate screening to detect complications of early stages of lung cancer for those with indium lung ${ }^{56}$. 


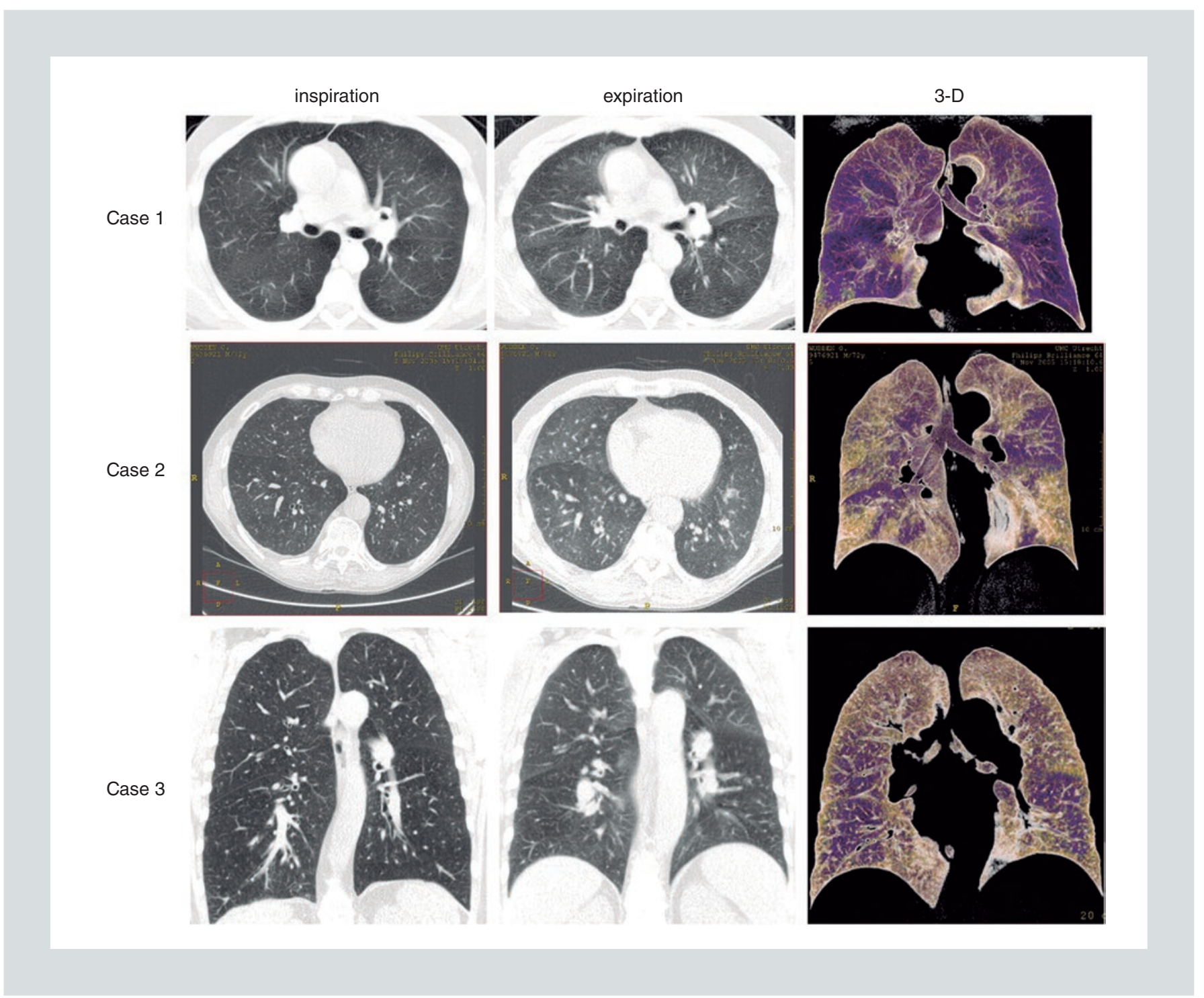

FIgURE 3. Diacetyl-associated obliterative bronchiolitis. Multislice high-resolution computed tomography scans of the lungs during inspiration (leftmost column) show inhomogeneity of the lung attenuation during inspiration. In Case 1 (top row), a slight mosaic pattern of the lung parenchyma is already present during inspiration. During expiration (middle column), a mosaic pattern is visible in all three cases. Note that areas in which lung density remains virtually unchanged are indicative of substantial air trapping. In expiratory three-dimensional color rendering of coronal 3-cm-thick sections of the lungs (rightmost column) inhomogeneity is even more pronounced with purple areas due to air trapping. Findings are compatible with bronchiolitis obliterans (reproduced from van Rooy FG et al. ${ }^{48}$ with permission of the American Thoracic Society; ‘ 2020 American Thoracic Society. All rights reserved).

Cummings and colleagues (2012) ${ }^{57}$ found interstitial lung disease (ILD) among ten men engaged in the production, use, and reclamation of indium compounds. Three of them had pulmonary alveolar proteinosis, nine fibrosis, and cholesterol clefts and granulomas were found in all the workers ${ }^{57}$ (Fig. 4). In subsequent follow-up studies conducted by $\mathrm{NIOSH}$, associations between higher cumulative respirable indium with more dyspnoea, lower spirometric parameters, and higher serum biomarkers of lung disease, such as Krebs 

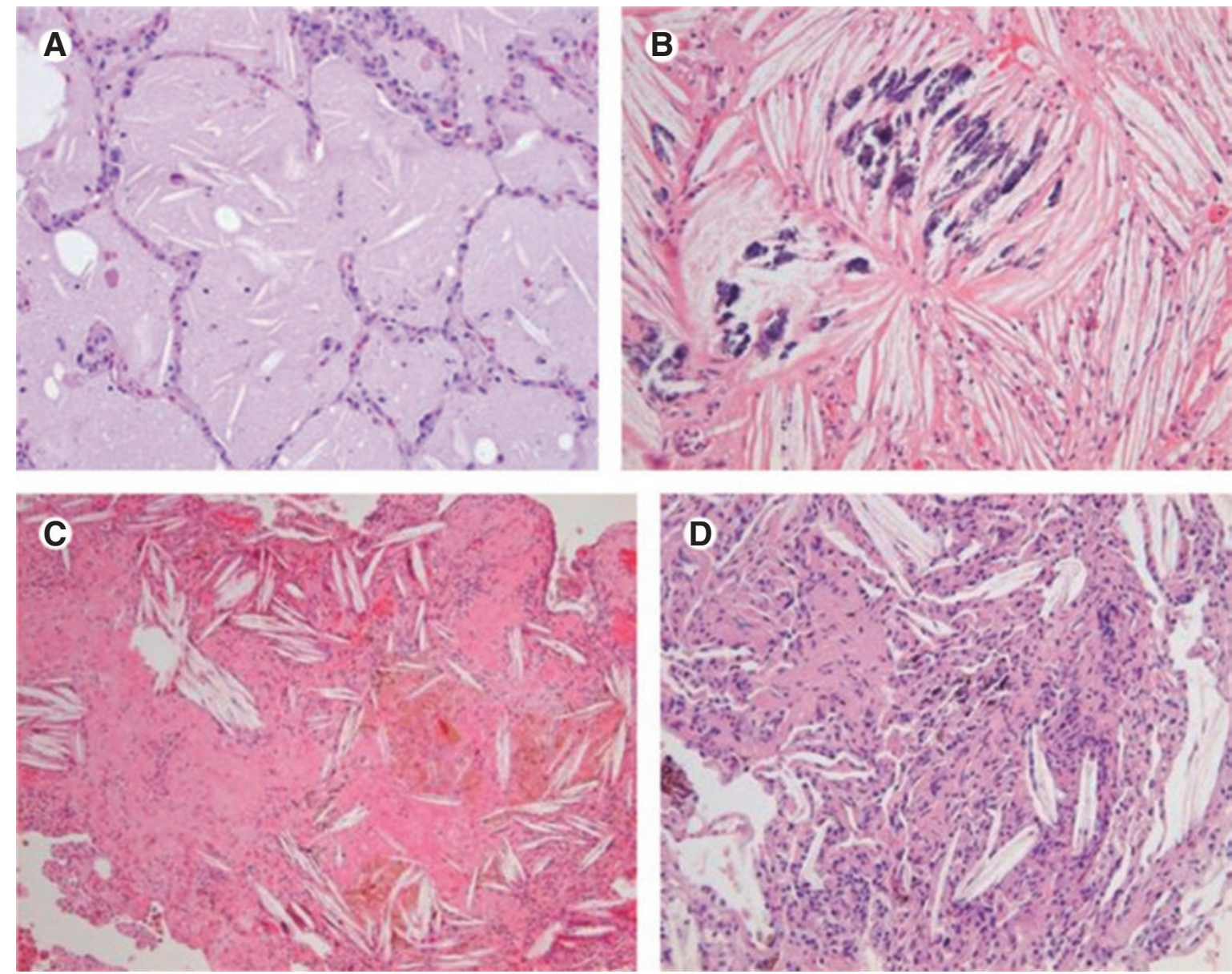

Figure 4. Indium lung disease. Spectrum of histopathologic features of indium lung disease (hematoxylin and eosin stains).

A: intraalveolar exudate characteristic of alveolar proteinosis, with occasional cholesterol clefts (magnification $\times 200$ ). B: innumerable cholesterol clefts (magnification $\times 200$ ). C: intraalveolar exudate characteristic of alveolar proteinosis, cholesterol clefts, and fibrosis (magnification $\times 100$ ). D: cholesterol clefts, associated multinucleated giant cells, interstitial fibrosis, and brown particles composed predominantly of indium (magnification $\times 200$ ) (reproduced from Cummings KJ et al..$^{57}$ with permission from Elsevier, (C) 2012 The American College of Chest Physicians. Published by Elsevier Inc. All rights reserved.)

von den Lungen-6 KL-6), and surfactant protein-D (SP-D) were also observed ${ }^{58,59}$. In another report ${ }^{60}, 21 \%$ of workers in an indium processing facility were found to have interstitial changes. By analysing the relationships between radiological observation pulmonary function tests, serum indium concentration, and KL-6, serum indium concentration was positively correlated with KL-6 level and degree of HRCT abnormalities ${ }^{60}$. Similar radiological features of interstitial abnormalities were observed in other studies from Japan between 2003 and 201055,61-63. An elevated level of autoantibodies to granulocyte macrophage-colony stimulating factor (GM-CSF) was found in a worker exposed to airborne ITO dust ${ }^{64}$. 
The mechanism of carcinogenicity of ITO has been investigated in laboratory animals and it was found that indium compounds including nanoparticles of $\operatorname{In}_{2} \mathrm{O}_{3}$, ITO, and indium chloride $\left(\mathrm{InCl}_{3}\right)$ significantly increased 8-Nitroguanine (8-nitroG; a mutagenic DNA lesion) formation and stimulated inflammation-mediated DNA damage in lung epithelial cells via the HMGB1-RAGE-TLR9 pathway which may contribute to genotoxicity in the respiratory system ${ }^{65}$.

ITO can cause irreversible changes in the lungs, and early detection could prevent such damages. Attention should be paid to mitigate the possible toxic effects of indium compounds. Improved indium-handling operations require respiratory protection from indium dust and stringent engineering control measures. Expert advice, including worker health checks for respiratory diseases and exposure measurement by air sampling, may help control the exposure ${ }^{66}$.

\section{Hairdressing chemicals}

When several chemicals used in salons were scrutinized in the early 90s for their toxic chemical properties ${ }^{67-71}$, much attention was paid to the reproductive health of the female hairdressers exposed to those chemicals. It was observed that solvents such as ethanol and dichloromethane found in hair sprays were mainly responsible for reproductive disorders in humans, however, other chemicals such as ethylene glycol ethers, nitrosamines, formaldehyde, hexachlorophene. Phthalic esters were also associated with reproductive disorders though few human data on low concentrations of these agents were available.
In 2001, Hollund and colleagues ${ }^{72}$ reported airway symptoms among a group of Norwegian hairdressers. This observation initiated several studies in the following years, which attempted to investigate indoor air quality and details of personal exposure to chemicals used in salons ${ }^{73-78}$.

Various bleaching products, dyes, and humidifiers used in the salons are potential sensitizers and irritants and can cause dermal allergic reactions ${ }^{79,80}$, which might often lead to respiratory ailments ${ }^{81}$. Several studies have demonstrated the prevalence of allergic conditions, such as dermatitis, allergic rhinitis, and asthma among hairdressers ${ }^{80-89}$. In a prospective cohort study, Nemer and colleagues ${ }^{83}$ found excess $35 \mathrm{ml} /$ year reduction of forced vital capacity (FVC), and of $31 \mathrm{ml} /$ year reduction of $\mathrm{FEV}_{1}$ in current hairdressers compared to former ones. One of the particular products predominantly present in hair straighteners is formaldehyde ${ }^{78,90}$, a known irritant. In a fifteen-minute exposure assessment in a beauty salon during hair straightening procedure, formaldehyde exposure concentration was found significantly higher than the National Institute for Occupational Safety and Health $(\mathrm{NIOSH})$ and the American Conference of Governmental Industrial Hygienist (ACGIH) permissible thresholds levels ${ }^{91}$. Occupational exposure to formaldehyde in hairdressing salons was found to be associated with asth$\mathrm{ma}^{86}$. Formaldehyde was also found significantly associated with micronucleus formation in peripheral blood lymphocytes and buccal cells ${ }^{78,91}$, and with a higher level of DNA damage in peripheral blood cells ${ }^{78,92}$. Several other studies also found that the concentration of formaldehyde in the indoor air often exceeds the permissible exposure limits of $\mathrm{OSHA}^{93}$. 
Another chemical used in hairdressing salons is ammonia, a key ingredient of bleaching products. The use of bleaching products often exposes the workers and customers to a high amount of ammonia. One report suggested that ammonia could cause bleaching-associated rhinitis ${ }^{88}$, while another report suggested that ammonia could be associated with neutrophilic airway inflammation, higher exhaled nitric oxide (eNO) levels and higher blood C-reactive protein (CRP) level ${ }^{84}$. Another report also demonstrated the use of elemental mercury in beauty salons, thus, imposing a greater health risk on the workers ${ }^{82}$. Other chemicals such as methacrylate, can sometimes cause dermatitis and allergic skin reactions ${ }^{95-97}$. Methacrylate is a long-known chemical often used in dental procedures and is a respiratory hazard. Exposure to methyl methacrylate was previously found to cause hypersensitivity pneumonitis in dental technicians ${ }^{98}$. The same agent has later been confirmed to cause asthma in salon workers ${ }^{99}$.

Persulfate compounds are considered some of the most potent hazardous substances causing occupational asthma among hairdressers. Several epidemiological reports have demonstrated the association between exposure to persulfates at hairdressing salons and the risk of occupational asthma ${ }^{100-103}$. Exposure to persulfates was associated with increased exhaled nitric oxide and the number of eosinophils in induced sputum ${ }^{102}$. Mechanistic studies demonstrate that ammonium persulfate activates basophils and mast cells by inducing oxidation of some amino acids, which could be one plausible mechanism for persulfate-induced occupational asthma ${ }^{104}$. However, the use of persulfates has been limited in hairdressing salons in present days and safety awareness among the hairdressers has helped to minimise the exposure.

Several reports have described the incidence of lung and skin cancer among hairdressers. Since most of those reports indicated the use of hazardous chemicals as the main reason for cancer incidence in the workers ${ }^{105-109}$, new policies have been implemented to reduce the use of those hazardous chemicals. A recent pooled analysis of case-control studies between 1985 and 2010 revealed that smoking has remained the major risk factor for lung cancer among hairdressers ${ }^{110}$. Intriguingly, asthma seems to more common among hairdressers these days. Hairdressers' asthma is now considered a new type of work-related asthma and is a growing health concern. Although cases of asthma are often not reported by small-scale entrepreneurs in this sector, public health awareness can be an important step towards minimising the burden of work-related health hazards. Large-scale epidemiological studies are still lacking, particularly those focusing on the long-term effects of the chemicals used in salons.

\section{Exposure to World Trade Centre (WTC) dusts}

The collapse of the twin towers of the World Trade Centre (WTC) on September 11, 2001, called for an unprecedented environmental emergency. The demolition of the buildings produced an enormous amount of dust and particulate matters that covered lower Manhattan and the surrounding neighbourhood for a long period of time. The first responders, such as the firefighters, police, and the rescue workers who were deployed at the site immediately 
after the incident encountered an unprecedented amount of ultrafine basic $(\mathrm{pH}$ range: 8.9-10) particulate matters $\left(\mathrm{PM}_{2.5}\right)$, and a very high amount of calcium and sulphur ${ }^{111}$.

Several reports have shown the impact of WTC dust exposure on respiratory health ${ }^{14,112-117}$. A field study of 183 clean-up and recovery workers found that $34 \%$ developed cough, $24 \%$ developed phlegm, and 19\% developed wheeze and that the prevalence rate was associated with the number of days worked at the site ${ }^{118}$. A longitudinal study of pulmonary function in 12,079 New York City Fire Department rescue workers showed a substantial $(372 \mathrm{ml})$ reduction of age-adjusted $\mathrm{FEV}_{1}$ during the year after 09/11, which was 12 times equal to their expected age-related decline. Chronic respiratory effect of WTC dust exposure includes bronchial hyperresponsiveness and lower respiratory symptoms including chronic bronchitis $^{114,115}$. Air trapping was the most predominant feature in the WTC-exposed workers with lower respiratory symptoms ${ }^{119-120}$.

Other than chronic respiratory problems due to WTC dust exposure, formerly exposed responders are experiencing even more destructive lung conditions after several years of exposure. One recent report described potential work-related pleural abnormalities in 1453 WTC responders who were followed-up after a median of 6.8 years ${ }^{116}$. One recent study has reported that former WTC responders also developed pulmonary fibrosis and the adjusted hazard ratio was nearly 5 -times higher in those with a very high level of exposure, and nearly 3-times higher in those with a medium level of dust exposure $^{121}$. In addition to fibrotic changes, several former WTC dust-exposed workers were also reported to develop sarcoid-like granulomatous diseases ${ }^{122}$.

WTC dust exposure is still an important exposure to monitor due to its complex nature and multifaceted target organ effects. Despite several long-running cohorts of WTC dust-exposed workers and residents, a longitudinal impact on the carcinogenicity of the dust exposure has not been monitored systematically. As asbestos was very much in use during the construction of the twin towers, the risk of mesothelioma could still be high and should be taken into consideration in the future.

\section{Hydraulic fracking and exposure to petrol/natural gas}

Hydraulic fracturing, or 'fracking', is a technique used to extract oil and natural gas. In this process, large amounts of pressurized mixtures of sand, water, and other chemicals are injected deep into wells to fracture the rock that allows the extraction of oil and natural gas. Despite a decline in the price of oil and natural gas in the past few years, fracking is booming. In the United States alone, more than 200,000 new wells are drilled and fractured every year, involving more than 200,000 workers by well servicing companies ${ }^{8,123,124}$. However, this process of natural gas extraction has raised potential concerns for its negative impact on the surrounding nature and on the people engaged in this operation or staying nearby ${ }^{8,123,125-130}$. Workers engaged in this sector are exposed to several hazardous substances including RCS, emissions from automobile engines, organic compounds such as benzene, toluene, and xylenes, ozone, reduced sulphur, and radon; all of these are known for 
occupational lung diseases, including silicosis, asthma and lung cancer ${ }^{8}$. Esswein and colleagues (2013) ${ }^{127}$ collected air samples from eleven fracking sites in the United States and found that in around $80 \%$ of the air samples, the concentration of silica had exceeded the relevant occupational PELs; the concentration was high enough to overwhelm the filtering capacity of the personal protective equipment of the workers ${ }^{128}$. In a report, the US Occupational Safety and Health Administration had also expressed its concern that fracking-associated silica exposure could lead to long-term respiratory effects in the workers ${ }^{131}$.

Other than silica, acids and heavy metals are some of the additives that are used in fracking. A huge amount of water mixed with these additives, such as corrosive acids, surfactants, and heavy metals are injected into the wells with high pressure that again is pulled out from the pits. This water contains several contaminants such as a high concentration of heavy metals, and several by-products including methanol and methyl mercury that have potential to cause adverse health effects including respiratory toxicity ${ }^{132,133}$. Some reports underestimated the potential hazard of fracking, simply by demonstrating under-represented studies and scientific evidence ${ }^{134}$. Animal studies using fracking sand dust as experimental exposure showed intratracheal installations of the dust particle that modulate the sodium ion $\left[\mathrm{Na}^{+}\right]$ channels of the airway epithelial cells ${ }^{135}$. However, the way fracking-associated occupational exposure affects the respiratory health of the workers, is not fully understood. Nevertheless, the increasing body of public health evidence of the adverse health effects of fracking is overwhelming and potentially warrants serious surveillance of the workers and the work environment.

Exposure to petroleum and natural gas is another emerging cause of occupational lung disease. The first case of lung cancer in filling station attendants was presented more than 30 years ago ${ }^{136}$. After that, several cases of exposure-associated lung diseases among petrol/gas filling stations have been reported to date ${ }^{137-139}$. A unique report on the cigarette lighter refilling process demonstrated that small vendors who refill hand-held cigarette lighters with liquefied petroleum gas remained exposed to a very high amount of volatile petrochemicals, which might be readily inhaled leading to respiratory problems ${ }^{140}$. However, these exposures are still undermined although the magnitude of such exposures is quite high in industrially developing countries. It is important to examine these occupational exposures thoroughly and also to educate the workers about the possible health hazards of such exposures.

\section{Nylon flocks}

In the industrial process of flocking, short lengths of synthetic fibres are applied to backing fabric to produce plush material. Nylon flock as a fibrogenic material was identified in the late 90s when workers of nylon-flock industries were diagnosed with interstitial pneumonitis ${ }^{141-143}$. An exposure assessment study found that the flock particles had a length of nearly one millimetre with a diameter of about 10-15 micron ${ }^{144}$. Flocking rooms were found to contain a very large amount of respirable particles of a concentration up to $240 \mathrm{mg}$ per cubic millimetre ${ }^{144}$. A follow-up 
study of nylon flock workers showed a wide array of pathological conditions in the lung biopsy samples, including desquamative interstitial pneumonia, and bilateral synchronous adenocarcinoma $^{145}$. A 10-year retrospective cohort study identified a three-fold increase in lung cancer incidence in workers exposed to nylon flocks ${ }^{146}$. Other studies have also demonstrated a progressive decline in pulmonary function, pulmonary hypertension, and respiratory failure among nylon flock industry workers ${ }^{147}$. Even though the nylon-flock-associated lung diseases are rarely reported these days, this specific exposure-associated lung disease was seminal in the last part of the $19^{\text {th }}$ century for its unique clinicopathological characteristics.

\section{Nanomaterials}

Nanomaterials are ultrafine particles with a length or diameter of $100 \mathrm{~nm}$. Most of these materials to which workers remain exposed are mostly generated as an unrecognizable by-product of a process. Recent reports have stated that occupational exposure to engineered nanomaterials are sometimes common, although identification of such exposure is extremely difficult. A case-control study in Taiwanese nanomaterial workers showed that exposure to engineered nanomaterials had been associated with aggravated symptoms of sneezing and allergic dermatitis ${ }^{148}$. The same group later also observed an increased expression of Club Cell secretory protein 16 (CC-16) and reduced pulmonary function in a group of nanomaterial workers in a longitudinal study ${ }^{149}$. Multi-wall carbon nanotubes (MWCNTs), a potentially important industrial and medical substance may affect the workers at the workplace during production. Some reports have demonstrated that workplace MWCNT exposure was associated with increased oxidative stress in the exhaled breath condensate of the workers $^{150}$, without any influence on lung function. Recently, a small case-control study on 22 MWCNT workers demonstrated that the exposure to MWCNT was associated with immunological parameters such as fractional exhaled nitric oxide (FENO), and other immune mediators, such as basic fibroblast growth factor but not with the pulmonary function test ${ }^{151}$. A similar relationship between occupational exposure to nanomaterials and FENO was also observed in another study ${ }^{152}$. Carboniferous nanomaterials can also be emitted from other sources, such as photocopiers and printers. Photocopiers emit a large amount of nanoparticles, primarily carbon nanoparticles, although this event has remained undetermined. An exposure-assessment study found that in most high-speed photocopy centres, the workstations had a high concentration of nanoparticles and no attention was paid to control emissions $^{153}$. Although some reports are cross-sectional and have a small sample size, some short-phase longitudinal studies with a larger sample size ( $\mathrm{n}=200-500)$ have also demonstrated adverse respiratory effects of carbon nanoparticle exposure at work.

There are some reports that have shown occupational exposure to other types of nanomaterial exposure at work. A workplace monitoring study in the ceramic industry revealed that the atmospheric plasma spraying (APS) process (a process for coating the surfaces of various materials to achieve enhanced material safety, insulation, or resistance against corrosion) generates ultrafine particles $(<100 \mathrm{~nm}$ in size) and nanoparticles $(<50 \mathrm{~nm})$ in the 
breathing zone of the workers ${ }^{154}$, thus might expose the workers to a high potential occupational hazard. Exposure to polyacrylate nanoparticles was found associated with pleural effusion, pulmonary fibrosis, and granuloma among seven female workers working in a print plant $^{155}$. Another study showed severe chemical pneumonitis with extensive bilateral ground-glass opacities in a worker exposed to nanosized positively charged fluorinated acrylate during spray painting wooden furnitures $^{156}$. In a cross-sectional study on 28 workers of a Chinese manufacturing industry, Li and colleagues $(2018)^{157}$ reported a significant reduction in lung function of the workers as a result of long-term exposure to nanosized calcium carbonate. Pelclova and colleagues ${ }^{158}$ found a trace of nanoparticles in the exhaled breath condensate (EBC) of the workers exposed to titanium dioxide $\left(\mathrm{TiO}_{2}\right)$ nanoparticles. The same group later demonstrated that occupational exposure to $\mathrm{TiO}_{2}$ nanoparticles was associated with increased FENO, lowered lung function, and increased production of cysteinyl leukotrienes in the EBC, suggesting aggravated pulmonary inflammation in those workers ${ }^{159}$. Zhao and colleagues $(2018)^{160}$ reported that workers exposed to engineered $\mathrm{TiO}_{2}$ nanoparticles had respiratory complications. $43 \%$ of the exposed workers had abnormalities in chest X-ray compared to $2 \%$ of unexposed workers. The median concentration of surfactant protein (SP)-D was also significantly lower among the exposed workers compared to those who were not exposed (3.61 versus $4.55 \mathrm{ng} / \mathrm{mL})^{160}$.

Despite the available evidence, there are still lacunae as critically speaking, as most of the studies lack rigorous statistical crosschecking such as (i) role of other residual confounders such as pre-existing respiratory health conditions, or any potential socio-environmental attributes, or (ii) influence of potential effect modifiers that might influence the exposure-response relationships, have rarely been investigated. Therefore, properly designed prospective epidemiological studies, particularly longitudinal studies, are needed.

\section{PREVENTION AND CONTROL}

The occurrence of occupational lung diseases can be prevented mainly in three ways: (i) reducing disease incidence (primary prevention), (ii) reducing the disease progression (secondary prevention), and (iii) reducing complications and consequences of an already developed disease (tertiary prevention). While primary prevention is the most desired one, the process comprises several steps of preventable measures (Fig. 5). In this hierarchical approach, the elimination of hazardous substances from the workplace is the most effective and primary requirement. Where such elimination is impossible, the introduction of a substitute should be prioritized. However, the plausible hazards of the alternative choice of material should be well verified before the implementation. Where elimination and substitution are impossible to implement, engineering control measures become optimal to reduce the exposure. Administrative and legislative approaches are also important in the mitigation of a safe workplace, however, it should be noted that personal protection stands at the lowest tier of this hierarchy, which means that personal protective equipment (PPEs) cannot replace the other 4 tiers of preventive measures and can only be implemented where other methods cannot be applied or have failed to contain the exposure ${ }^{1}$. 


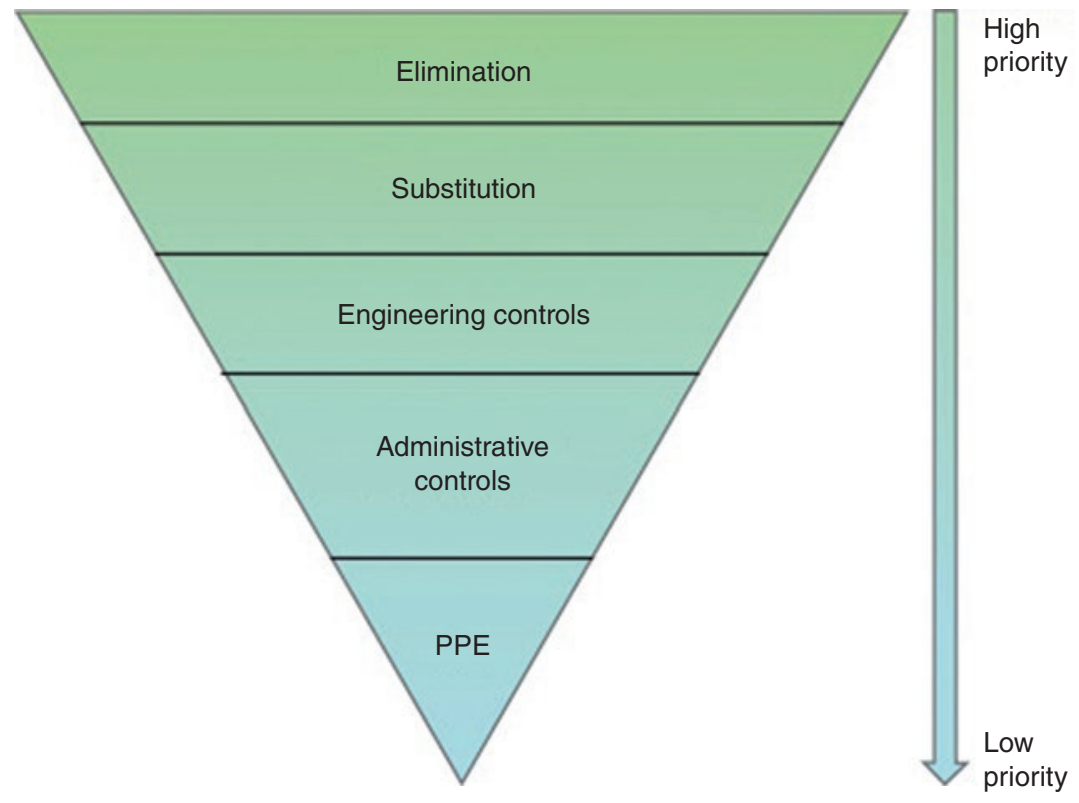

Figure 5. The hierarchy of control used in managing hazardous exposures in the workplace (reproduced from Cullinan $P$ et al. ${ }^{1}$ with permission from The Lancet Respiratory Medicine, (C) 2017 Elsevier Ltd. All rights reserved).

PPE: personal protective equipment.

Although pre-employment screening for a pre-existent disease could safeguard the workers from probable workplace hazards ${ }^{161}$, this method is almost non-existent and rarely implemented in developing countries because of an easily replaceable workforce. Workers often do not complain about their exposures because of probable job loss despite long-term exposure to workplace hazards. However, regular surveillance could turn out to be the best possible way to render preventive measures by modulating primary, secondary, or tertiary measures, individually or by combination.

Exposure to new materials in the workplace is unavoidable as we move forward with the globalization and industrial revolution.
Therefore, workers' awareness and education programmes about the potential health hazards of the materials used should be prioritized. Regular monitoring of workplaces is crucial and regular health monitoring of the workers should be guaranteed.

\section{CONCLUSION}

Occupational lung diseases have been a major problem not only in developing countries but also in developed countries. Unfortunately, despite its impact on millions of workers leading to serious health issues, this scenario garners disproportionately less attention than other contemporary environmental and lifestyle factors. Preventive measures can be 
implemented albeit applicable to very few sectors. With the advent of new technologies and materials, exposure-associated health hazards are rapidly increasing, making the disease diagnosis, management, and prevention more complicated. Efforts must be taken to monitor the trends in known sources of occupational hazards, evaluate health impact and causality, and develop strategies to identify and manage new hazards.

\section{DISCLOSURES}

Dr. Moitra reports personal fees from the European Respiratory Society and Synergy Respiratory \& Cardiac Care, grants from the European Respiratory Society, and non-financial support from Oxford Publications; all outside the submitted work. Dr. Haldar reports personal fees from the European Respiratory Society outside the submitted work.

\section{REFERENCES}

1. Cullinan P, Munoz X, Suojalehto H et al. Occupational lung diseases: from old and novel exposures to effective preventive strategies. Lancet Respir Med. 2017;5:445-55.

2. Collaborators GOCRRF. Global and regional burden of chronic respiratory disease in 2016 arising from non-infectious airborne occupational exposures: a systematic analysis for the Global Burden of Disease Study 2016. Occup Environ Med. 2020;77:142-50.

3. Dhara R, Acquilla S, Cullinan P. Has the world forgotten Bhopal? Lancet 2001;357:809-10.

4. Crabb C. Revisiting the Bhopal Tragedy. Science 2004;306:1670-1.

5. Senthilkumar CS, Sah NK, Ganesh N. On the long-term effects of methyl isocyanate on cell-mediated immunity in Bhopal gas-exposed long-term survivors and their offspring. Toxicol Ind Health 2016;33:318-31.

6. Jindal SK. Silicosis in India: past and present. Curr Opin Pulm Med. 2013; 19:163-8

7. Nelson G, Girdler-Brown B, Ndlovu N, Murray J. Three decades of silicosis: disease trends at autopsy in South African gold miners. Environ Health Perspect. 2010;118:421-6.

8. Moitra S, Puri R, Paul D, Huang Y-CT. Global perspectives of emerging occupational and environmental lung diseases. Curr Opin Pulm Med. 2015;21:114-20.

9. Venter E, Nyantumbu B, Solomon A, Rees D. Radiologic Abnormalities in South African Mica Millers: A Survey of a Mica Milling Plant in the Limpopo Province. Int J Occup Environ Health 2004;10:278-83.
10. Kobayashi H, Ohara I, Kanoh S, Motoyoshi K, Aida S, Kohyama N. Clinicopathological features of pure mica pneumoconiosis associated with Sjögren syndrome. Am J Ind Med. 2004;45:246-50.

11. Hulo S, Cherot-kornobis N, Edme J-L et al. Mica Dust and Pneumoconiosis. J Occup Environ Med. 2013;55:1469-74.

12. Moitra S, Bandyopadhyay A, Moitra S. Mica pneumoconiosis: a neglected occupational lung disease. Lancet Respir Med. 2018;6:e39.

13. Moitra S, Farshchi Tabrizi A, Idrissi Machichi Ket al. Non-Malignant Respiratory Illnesses in Association with Occupational Exposure to Asbestos and Other Insulating Materials: Findings from the Alberta Insulator Cohort. Int J Environ Res Public Health 2020;17:7085

14. Maslow CB, Friedman SM, Pillai PS et al. Chronic and Acute Exposures to the World Trade Center Disaster and Lower Respiratory Symptoms: Area Residents and Workers. Am J Public Health 2012;102:1186-94.

15. Hoy RF, Chambers DC. Silica-related diseases in the modern world. Allergy. 2020

16. Akgun M, Mirici A, Ucar EY, Kantarci M, Araz O, Gorguner M. Silicosis in Turkish denim sandblasters. Occup Med. 2006;56:554-8.

17. Akgun M, Araz O, Akkurt I et al. An epidemic of silicosis among former denim sandblasters. Eur Respir J. 2008;32:1295-303.

18. Bakan ND, Özkan G, Çamsari G et al. Silicosis in Denim Sandblasters. Chest 2011;140:1300-4.

19. Akgun M, Ucar EY, Araz O, Parker JE. Prognosis of patients with silicosis due to denim sandblasting. Chest 2012;141:831.

20. Akgun M, Araz O, Ucar EY et al. Silicosis Appears Inevitable Among Former Denim Sandblasters. Chest 2015;148:647-54.

21. Akgün M. Denim production and silicosis. Cur Opin Pulm Med. 2016;22: 165-9.

22. Barmania S. Deadly denim: sandblasting-induced silicosis in the jeans industry. Lancet Respir Med. 2016;4:543.

23. Alper F, Akgun M, Onbas O, Araz O. CT findings in silicosis due to denim sandblasting. Eur Radiol. 2008;18:2739-44.

24. Sahbaz S, Inonu H, Ocal S et al. Denim sandblasting and silicosis two new subsequent cases in Turkey. Tuberk Toraks. 2007;55:87-91.

25. Palabiyik SS, Girgin G, Tutkun E, Yilmaz ÖH, Baydar T. Immunomodulation and Oxidative Stress in Denim Sandblasting Workers: Changes Caused by Silica Exposure. Arch Indus Hyg Toxicol. 2013;64:431-7.

26. Deniz O, Gumus S, Ors F, Yaman H et al. Serum lactate dehydrogenase levels significantly correlate with radiological extent of disease and spirometric values in patients with silicosis due to denim sandblasting. Clin Chem Lab Med. 2012;50.

27. Dogan H, Akgun M, Araz O et al. The association of human leukocyte antigen polymorphisms with disease severity and latency period in patients with silicosis. Multidiscip Respir Med. 2014;9.

28. Ozden K, Araz O, Yilmazel Ucar E, Alper F, Akgun M. Co-Existence of Tuberculous Meningitis and Pulmonary Tuberculosis in a Denim Sandblaster. Eurasian J Med. 2012;44:54-7.

29. Yildiz T. Quality of life, depression and anxiety in young male patients with silicosis due to denim sandblasting. Tuberk Toraks. 2011;59:120-5.

30. Carrieri M, Guzzardo C, Farcas D, Cena LG. Characterization of Silica Exposure during Manufacturing of Artificial Stone Countertops. Int J Environ Res Public Health. 2020;17.

31. Ophir N, Shai AB, Alkalay Y et al. Artificial stone dust-induced functional and inflammatory abnormalities in exposed workers monitored quantitatively by biometrics. ERJ Open Res. 2016;2.

32. Hoy RF, Baird T, Hammerschlag G et al. Artificial stone-associated silicosis: a rapidly emerging occupational lung disease. Occup Environ Med. 2018;75:3-5.

33. Ronsmans S, Decoster L, Keirsbilck S, Verbeken EK, Nemery B. Artificial stone-associated silicosis in Belgium. Occup Environ Med. 2019;76:133-4.

34. Queensland W. Managing respirable crystalline silica in bench top fabrication. Injury prevention safety advice. 2019 [updated 22/10/2019. Available from: https://www.worksafe.qld.gov.au/_data/assets/pdf_file/0013/32413/ managing-respirable-crystalline-silica-dust-exposure-in-the-stone-benchtopindustry-code-of-practice-2019.pdf]. 
35. Pavan C, Polimeni M, Tomatis M et al. Editor's Highlight: Abrasion of Artificial Stones as a New Cause of an Ancient Disease. Physicochemical Features and Cellular Responses. Toxicol Sci. 2016;153:4-17.

36. Buchanan D, Miller BG, Soutar CA. Quantitative relations between exposure to respirable quartz and risk of silicosis. Occup Environ Med. 2003;60:159-64.

37. Barber CM, Fishwick D, Seed MJ, Carder M, van Tongeren M. Artificial stone-associated silicosis in the UK. Occup Environ Med. 2018;75:541.

38. Newbigin K, Parsons R, Deller D, Edwards R, McBean R. Stonemasons with silicosis: Preliminary findings and a warning message from Australia. Respirology. 2019;24:1220-1.

39. Ophir N, Bar Shai A, Korenstein R, Kramer MR, Fireman E. Functional, inflammatory and interstitial impairment due to artificial stone dust ultrafine particles exposure. Occup Environ Med. 2019;76:875-9.

40. Grubstein A, Shtraichman O, Fireman E, Bachar GN, Noach-Ophir N, Kramer MR. Radiological Evaluation of Artificial Stone Silicosis Outbreak: Emphasizing Findings in Lung Transplant Recipients. J Comput Assist Tomogr. 2016;40:923-7

41. Levin K, McLean C, Hoy R. Artificial stone-associated silicosis: clinical-pathological-radiological correlates of disease. Respirol Case Rep. 2019;7:e00470.

42. Jones CM, Pasricha SS, Heinze SB, MacDonald S. Silicosis in artificial stone workers: Spectrum of radiological high-resolution CT chest findings. J Med Imaging Radiat Oncol. 2020;64:241-9.

43. Kreiss K, Gomaa A, Kullman G, Fedan K, Simoes EJ, Enright PL. Clinical Bronchiolitis Obliterans in Workers at a Microwave-Popcorn Plant. N Engl J Med. 2002;347:330-8.

44. Kreiss K, Fedan KB, Nasrullah M et al. Longitudinal lung function declines among California flavoring manufacturing workers. Am J Ind Med. 2012; 55:657-68.

45. Boylstein R, Piacitelli C, Grote A, Kanwal R, Kullman G, Kreiss K. Diacetyl emissions and airborne dust from butter flavorings used in microwave popcorn production. J Occup Environ Hyg. 2006;3:530-5.

46. Lockey JE, Hilbert TJ, Levin LP et al. Airway obstruction related to diacetyl exposure at microwave popcorn production facilities. Eur Respir J. 2009;34:63-71.

47. Centers for Disease C, Prevention. Fixed obstructive lung disease among workers in the flavor-manufacturing industry--California, 2004-2007. MMWR Morb Mortal Wkly Rep. 2007;56:389-93.

48. van Rooy FG, Rooyackers JM, Prokop M, Houba R, Smit LA, Heederik DJ. Bronchiolitis obliterans syndrome in chemical workers producing diacetyl for food flavorings. Am J Respir Crit Care Med. 2007;176:498-504.

49. Hendrick DJ. "Popcorn worker's lung" in Britain in a man making potato crisp flavouring. BMJ Case Rep. 2009;2009.

50. Duling MG, LeBouf RF, Cox-Ganser JM, Kreiss K, Martin SB, Jr., Bailey RL. Environmental characterization of a coffee processing workplace with obliterative bronchiolitis in former workers. J Occup Environ Hyg. 2016;13:770-81.

51. Hubbs AF, Kreiss K, Cummings KJ et al. Flavorings-Related Lung Disease: A Brief Review and New Mechanistic Data. Toxicol Pathol. 2019;47:1012-26.

52. Sauler M, Gulati M. Newly Recognized Occupational and Environmental Causes of Chronic Terminal Airways and Parenchymal Lung Disease. Clin Chest Med. 2012;33:667-80.

53. Bomhard EM. The toxicology of indium oxide. Environ Toxicol Pharmacol. 2018;58:250-8

54. Lokanc M, Eggert R, Redlinger M. The Availability of Indium: The Present, Medium Term, and Long Term 2015 [Available from: https:/ / www.nrel.gov/ docs/fy16osti/62409.pdf.

55. Homma T, Ueno T, Sekizawa K, Tanaka A, Hirata M. Interstitial pneumonia developed in a worker dealing with particles containing indium-tin oxide. J Occup Health 2003;45(3):137-9.

56. Chonan T, Amata A, Kawabata Y, Omae K. Indium Lung: Discovery, Pathophysiology and Prevention. Tohoku J Exp Med. 2019;248:143-50.

57. Cummings KJ, Nakano M, Omae K et al. Indium lung disease. Chest 2012; 141:1512-21.

58. Cummings KJ, Virji MA, Park JY et al. Respirable indium exposures, plasma indium, and respiratory health among indium-tin oxide (ITO) workers. Am J Ind Med. 2016;59:522-31.
59. Cummings KJ, Virji MA, Trapnell BC, Carey B, Healey T, Kreiss K. Early changes in clinical, functional, and laboratory biomarkers in workers at risk of indium lung disease. Ann Am Thorac Soc. 2014;11:1395-403.

60. Chonan T, Taguchi O, Omae K. Interstitial pulmonary disorders in indium-processing workers. Eur Respir J. 2007;29:317-24.

61. Homma S, Miyamoto A, Sakamoto S, Kishi K, Motoi N, Yoshimura K. Pulmonary fibrosis in an individual occupationally exposed to inhaled indium-tin oxide. Eur Respir J. 2005;25:200-4.

62. Nakano M, Omae K, Tanaka A et al. Causal relationship between indium compound inhalation and effects on the lungs. J Occup Health 2009;51:513-21.

63. Omae K, Nakano M, Tanaka A, Hirata M, Hamaguchi T, Chonan T. Indium lung--case reports and epidemiology. Int Arch Occup Environ Health. 2011; $84: 471-7$.

64. Cummings KJ, Donat WE, Ettensohn DB, Roggli VL, Ingram P, Kreiss K. Pulmonary alveolar proteinosis in workers at an indium processing facility. Am J Respir Crit Care Med. 2010;181:458-64.

65. Ahmed S, Kobayashi H, Afroz T et al. Nitrative DNA damage in lung epithelial cells exposed to indium nanoparticles and indium ions. Sci Rep. 2020;10:10741.

66. Higashikubo I, Arito H, Ando K, Araki A, Shimizu H, Sakurai H. Control banding assessment of workers' exposure to indium and its compounds in 13 Japanese indium plants. J Occup Health. 2018;60:263-70.

67. Kersemaekers WM, Roeleveld N, Zielhuis GA. Reproductive disorders due to chemical exposure among hairdressers. Scand J Work Environ Health. 1995;21:325-34.

68. Occupational exposures of hairdressers and barbers and personal use of hair colourants. IARC Monogr Eval Carcinog Risks Hum. 1993;57:43-118.

69. IARC working group on the evaluation of carcinogenic risks to humans: occupational exposures of hairdressers and barbers and personal use of hair colourants; some hair dyes, cosmetic colourants, industrial dyestuffs and aromatic amines. Proceedings. Lyon, France, 6-13 October 1992. IARC Monogr Eval Carcinog Risks Hum. 1993;57:7-398.

70. van Muiswinkel WJ, Kromhout H, Onos T, Kersemaekers W. Monitoring and modelling of exposure to ethanol in hairdressing salons. Ann Occup Hyg. 1997;41:235-47.

71. Kersemaekers WM, Verheijen N, Kromhout H, Roeleveld N, Zielhuis GA Assessment of exposure to solvents among hairdressers: reliability of a classification scheme and questionnaire. Occup Environ Med. 1998;55:37-42.

72. Hollund BE, Moen BE, Lygre SH, Florvaag E, Omenaas E. Prevalence of airway symptoms among hairdressers in Bergen, Norway. Occup Environ Med. 2001;58:780-5.

73. Van Tongeren M, Nieuwenhuijsen MJ, Gardiner K et al. A job-exposure matrix for potential endocrine-disrupting chemicals developed for a study into the association between maternal occupational exposure and hypospadias. Ann Occup Hyg. 2002;46:465-77.

74. Labrèche F, Forest J, Trottier M, Lalonde M, Simard R. Characterization of chemical exposures in hairdressing salons. Appl Occup Environ Hyg. 2003;18:1014-21.

75. Evci ED, Bilgin MD, Akgör S, Zencirci SG, Ergi冈 F, Be冈er E. Measurement of selected indoor physical environmental factors in hairdresser salons in a Turkish City. Environ Monit Assess. 2007;134:471-7.

76. Ronda E, Hollund BE, Moen BE. Airborne exposure to chemical substances in hairdresser salons. Environ Monit Assess. 2009;153:83-93.

77. Oikawa D, Takeuchi W, Murata S, Takahashi K, Sekine Y. Measurement of concentrations of thioglycolic acid, dithiodiglycolic acid and ammonia in indoor air of a beauty salon. J Occup Health 2012;54:370-5.

78. Peteffi GP, Antunes MV, Carrer $\mathrm{C}$ et al. Environmental and biological monitoring of occupational formaldehyde exposure resulting from the use of products for hair straightening. Environ Sci Pollut Res Int. 2016;23:908-17.

79. Lind ML, Boman A, Sollenberg J, Johnsson S, Hagelthorn G, Meding B. Occupational dermal exposure to permanent hair dyes among hairdressers. Ann Occup Hyg. 2005;49:473-80.

80. Omokhodion FO, Balogun MO, Ola-Olorun FM. Reported occupational hazards and illnesses among hairdressers in Ibadan, Southwest Nigeria. West Afr J Med. 2009;28:20-3. 
81. Nemer M, Kristensen P, Nijem K, Bjertness E, Skogstad M. Respiratory function and chemical exposures among female hairdressers in Palestine. Occup Med. 2013;63:73-6.

82. Fakour H, Esmaili-Sari A. Occupational and environmental exposure to mercury among Iranian hairdressers. J Occup Health 2014;56:56-61.

83. Nemer M, Kristensen P, Nijem K, Bjertness E, Skare Ø, Skogstad M. Lung function and respiratory symptoms among female hairdressers in Palestine: a 5-year prospective study. BMJ Open 2015;5:e007857.

84. Nemer M, Sikkeland LI, Kasem M et al. Airway inflammation and ammonia exposure among female Palestinian hairdressers: a cross-sectional study. Occup Environ Med. 2015;72:428-34

85. Adewumi-Gunn TA, Ponce E, Flint N, Robbins W. A Preliminary Community-Based Occupational Health Survey of Black Hair Salon Workers in South Los Angeles. J Immigr Minor Health. 2018;20:164-70.

86. Dahlgren JG, Talbott PJ. Asthma from hair straightening treatment containing formaldehyde: Two cases and a review of the literature. Toxicol Ind Health 2018;34:262-9.

87. Quiros-Alcala L, Pollack AZ, Tchangalova N, DeSantiago M, Kavi LKA. Occupational Exposures Among Hair and Nail Salon Workers: a Scoping Review. Curr Environ Health Rep. 2019;6:269-85.

88. Nielsen J, Nilsson P, Dahlman-Hoglund A et al. Dust-free bleaching powder may not prevent symptoms in hairdressers with bleaching-associated rhinitis. J Occup Health 2016;58:470-6.

89. Skoufi GI, Nena E, Kostikas K, Lialios GA, Constantinidis TC, Daniil Z, et al. Work-related respiratory symptoms and airway disease in hairdressers. Int J Occup Environ Med. 2013;4:53-60.

90. Pexe ME, Marcante A, Luz MS et al. Hairdressers are exposed to high concentrations of formaldehyde during the hair straightening procedure. Environ Sci Pollut Res Int. 2019;26:27319-29.

91. Aglan MA, Mansour GN. Hair straightening products and the risk of occupational formaldehyde exposure in hairstylists. Drug Chem Toxicol. 2020; 43:488-95.

92. Barbosa E, Dos Santos ALA, Peteffi GP et al. Increase of global DNA methylation patterns in beauty salon workers exposed to low levels of formaldehyde. Environ Sci Pollut Res Int. 2019;26:1304-14.

93. Chang CJ, Cheng SF, Chang PT, Tsai SW. Indoor air quality in hairdressing salons in Taipei. Indoor Air. 2018;28:173-80.

94. Quach T, Gunier R, Tran A et al. Characterizing workplace exposures in Vietnamese women working in California nail salons. Am J Public Health 2011;101(Suppl 1):S271-6.

95. White H, Khan K, Lau C, Leung H, Montgomery D, Rohlman DS. Identifying Health and Safety Concerns in Southeast Asian Immigrant Nail Salon Workers. Arch Environ Occup Health 2015;70:196-203.

96. Henriks-Eckerman ML, Korva M. Exposure to airborne methacrylates in nail salons. J Occup Environ Hyg. 2012;9:D146-50.

97. DeKoven S, DeKoven J, Holness DL. (Meth)Acrylate Occupational Contact Dermatitis in Nail Salon Workers: A Case Series. J Cutan Med Surg. 2017;21:340-4.

98. Scherpereel A, Tillie-Leblond I, Pommier de Santi P, Tonnel AB. Exposure to methyl methacrylate and hypersensitivity pneumonitis in dental technicians. Allergy. 2004;59:890-2.

99. Sauni R, Kauppi P, Alanko K, Henriks-Eckerman ML, Tuppurainen M, Hannu T. Occupational asthma caused by sculptured nails containing methacrylates. Am J Ind Med. 2008;51:968-74.

100. Pablo Anconetani J, Isabel Badorrey M, Monsó E, Morera J. Asma laboral por persulfatos: escasa utilidad diagnóstica de la determinación del flujo espiratorio máximo en el lugar de trabajo. Med Clin (Barc). 2001;116:355-6.

101. Muñoz X, Cruz M-J, Orriols R, Bravo C, Espuga M, Morell F. Occupational Asthma Due to Persulfate Saltsa. Chest. 2003;123:2124-9.

102. Polychronakis I, Thanasias E, Raulf-Heimsoth M, Merget R. Occupational Non-immediate Type Allergic Asthma due to Ammonium Persulfate. Adv Exp Med Biol. 2013;755:79-84.

103. Le Moual N, Zock J-P, Dumas O et al. Update of an occupational asthma-specific job exposure matrix to assess exposure to 30 specific agents. Occup Environ Med. 2018;75:507-14.
104. Pignatti P, Frossi B, Pala G et al. Oxidative Activity of Ammonium Persulfate Salt on Mast Cells and Basophils: Implication in Hairdressers' Asthma. Int Arch Allergy Immunol. 2013;160:409-19.

105. Skov T, Lynge E. Cancer Risk and Exposures to Carcinogens in Hairdressers. Skin Pharmacol Physiol. 1994;7:94-100.

106. Pukkala E, Nokso-Koivisto P, Roponen P. Changing cancer risk pattern among Finnish hairdressers. Int Arch Occup Environ Health. 1992;64:39-42.

107. Lamba AB, Ward MH, Weeks JL, Dosemeci M. Cancer Mortality Patterns Among Hairdressers and Barbers in 24 US States, 1984 to 1995. J Occup Environ Med. 2001;43:250-8.

108. Czene K, Tiikkaja S, Hemminki K. Cancer risks in hairdressers: Assessment of carcinogenicity of hair dyes and gels. Int J Cancer. 2003;105:108-12.

109. Takkouche B, Regueira-Mendez C, Montes-Martinez A. Risk of cancer among hairdressers and related workers: a meta-analysis. Int J Epidemiol. 2009;38:1512-31.

110. Olsson AC, Xu Y, Schuz J et al. Lung Cancer Risk Among Hairdressers: A Pooled Analysis of Case-Control Studies Conducted Between 1985 and 2010 Am J Epidemiol. 2013;178:1355-65.

111. Gavett SH. World Trade Center fine particulate matter--chemistry and toxic respiratory effects: an overview. Environ Health Perspect. 2003;111:971.

112. Banauch GI, Hall C, Weiden M et al. Pulmonary Function after Exposure to the World Trade Center Collapse in the New York City Fire Department. Am J Respir Crit Care Med. 2006;174(3):312-9.

113. Mauer MP, Cummings KR. Impulse Oscillometry and Respiratory Symptoms in World Trade Center Responders, 6 Years Post-9/11. Lung. 2009;188:107-13.

114. Mauer MP, Cummings KR, Hoen R. Long-term respiratory symptoms in World Trade Center responders. Occup Med. 2009;60:145-51.

115. Aldrich TK, Weakley J, Dhar S et al. Bronchial Reactivity and Lung Function After World Trade Center Exposure. Chest. 2016;150:1333-40.

116. de la Hoz RE, Weber J, Xu D et al. Chest CT scan findings in World Trade Center workers. Arch Environ Occup Health. 2018;74:263-70.

117. Singh A, Liu C, Putman B et al. Predictors of Asthma/COPD Overlap in FDNY Firefighters With World Trade Center Dust Exposure. Chest. 2018;154:1301-10.

118. Herbstman JB, Frank R, Schwab M et al. Respiratory effects of inhalation exposure among workers during the clean-up effort at the World Trade Center disaster site. Environ Res. 2005;99:85-92.

119. Mendelson DS, Roggeveen M, Levin SM, Herbert R, de la Hoz RE. Air Trapping Detected on End-Expiratory High-Resolution Computed Tomography in Symptomatic World Trade Center Rescue and Recovery Workers. J Occup Environ Med. 2007;49:840-5.

120. de la Hoz RE, Liu X, Doucette JT et al. Increased Airway Wall Thickness is Associated with Adverse Longitudinal First-Second Forced Expiratory Volume Trajectories of Former World Trade Center workers. Lung. 2018;196:481-9.

121. Li J, Cone J, Brackbill R, Giesinger I, Yung J, Farfel M. Pulmonary Fibrosis among World Trade Center Responders: Results from the WTC Health Registry Cohort. Int J Environ Res Public Health. 2019;16:825.

122. Sunil V, Radbel J, Hussain S et al. Sarcoid-Like Granulomatous Disease: Pathologic Case Series in World Trade Center Dust Exposed Rescue and Recovery Workers. Int J Environ Res Public Health. 2019;16:815.

123. Kovats S, Depledge M, Haines A et al. The health implications of fracking. Lancet. 2014;383:757-8

124. Wilke RA, Freeman JW. Potential Health Implications Related to Fracking. JAMA. 2017;318:1645-6.

125. Bamber AM, Hasanali SH, Nair AS et al. A Systematic Review of the Epidemiologic Literature Assessing Health Outcomes in Populations Living near Oil and Natural Gas Operations: Study Quality and Future Recommendations. Int J Environ Res Public Health. 2019;16:2123.

126. Carpenter DO. Hydraulic fracturing for natural gas: impact on health and environment. Rev Environ Health. 2016;31.

127. Stacy SL. A Review of the Human Health Impacts of Unconventional Natural Gas Development. Curr Epidemiol Rep. 2017;4:38-45.

128. Esswein EJ, Breitenstein M, Snawder J, Kiefer M, Sieber WK. Occupational exposures to respirable crystalline silica during hydraulic fracturing. J Occup Environ Hyg. 2013;10:347-56. 
129. Glauser W. New legitimacy to concerns about fracking and health. CMAJ. 2014;186:E245-6.

130. Johnston JE, Lim E, Roh H. Impact of upstream oil extraction and environmental public health: A review of the evidence. Sci Total Environ. 2019;657:187-99.

131. Paris C, Do P, Mastroianni B, Dixmier A et al. Association between lung cancer somatic mutations and occupational exposure in never-smokers. Eur Respir J. 2017;50:1700716.

132. Latov N, Kumar G, Vo ML et al. Elevated blood mercury levels in idiopathic axonal neuropathy. JAMA Neurol. 2015;72:474-5.

133. Collister D, Duff G, Palatnick W, Komenda P, Tangri N, Hingwala J. A Methanol Intoxication Outbreak From Recreational Ingestion of Fracking Fluid. Am J Kidney Dis. 2017;69:696-700.

134. Torjesen I. Fracking poses little risk to public health, but evidence is limited. BMJ. 2013;347:f6626-f.

135. Russ KA, Thompson JA, Reynolds JS, et al. Biological effects of inhaled hydraulic fracturing sand dust. IV. Pulmonary effects. Toxicol Appl Pharmacol. 2020;409:115284.

136. Grandjean P, Andersen O. Lung cancer in filling station attendants. Am J Ind Med. 1991;20:763-8.

137. Rahimi Moghadam S, Afshari M, Moosazadeh M, Khanjani N, Ganjali A. The effect of occupational exposure to petrol on pulmonary function parameters: a review and meta-analysis. Rev Environ Health. 2019;34:377-90.

138. Lynge E, Andersen A, Nilsson R et al. Risk of Cancer and Exposure to Gasoline Vapors. Am J Epidemiol. 1997;145:449-58.

139. Lee SM, Moon $\mathrm{CH}$, Oh YB et al. Giant-cell interstitial pneumonia in a gas station worker. J Korean Med Sci. 1998;13:545.

140. Moitra S, Blanc PD, Brashier BB. Airflow obstruction among street vendors who refill cigarette lighters with liquefied petroleum gas. Int J Tuberc Lung Dis. 2014;18:1126-31.

141. Eschenbacher WL, Kreiss K, Lougheed MD, Pransky GS, Day B, Castellan RM. Nylon Flock-Associated Interstitial Lung Disease. Am J Respir Crit Care Med. 1999;159:2003-8.

142. Kern DG. Flock Worker's Lung: Chronic Interstitial Lung Disease in the Nylon Flocking Industry. Ann Intern Med. 1998;129:261.

143. Boag AH, Colby TV, Fraire AE et al. The Pathology of Interstitial Lung Disease in Nylon Flock Workers. Am J Surg Pathol. 1999;23:1539.

144. Joseph Burkhart CP. Environmental Study of Nylon Flocking Process. J Toxicol Environ Health A. 1999;57:1-23.

145. Kern DG, Kuhn C, Ely EW et al. Flock Worker's Lung: broadening the spectrum of clinicopathology, narrowing the spectrum of suspected etiologies. Chest. 2000;117:251-9.

146. Kern DG, Kern E, Crausman RS, Clapp RW. A Retrospective Cohort Study of Lung Cancer Incidence in Nylon Flock Workers, 1998-2008. Int J Occup Environ Health. 2011;17:345-51.
147. Turcotte SE, Chee A, Walsh R et al. Flock Worker's Lung Disease: natural history of cases and exposed workers in Kingston, Ontario. Chest. 2013;143: 1642-8.

148. Liao HY, Chung YT, Lai CH, Lin MH, Liou SH. Sneezing and allergic dermatitis were increased in engineered nanomaterial handling workers. Ind Health. 2014;52:199-215.

149. Liao HY, Chung YT, Lai CH et al. Six-month follow-up study of health markers of nanomaterials among workers handling engineered nanomaterials. Nanotoxicology. 2014;8 Suppl 1:100-10.

150. Lee JS, Choi YC, Shin JH, Lee JH et al. Health surveillance study of workers who manufacture multi-walled carbon nanotubes. Nanotoxicology. 2015; 9:802-11.

151. Vlaanderen J, Pronk A, Rothman N, Hildesheim A, Silverman D, Hosgood $\mathrm{HD}$, et al. A cross-sectional study of changes in markers of immunological effects and lung health due to exposure to multi-walled carbon nanotubes. Nanotoxicology. 2017;11:395-404.

152. Wu WT, Liao HY, Chung YT et al. Effect of nanoparticles exposure on fractional exhaled nitric oxide (FENO) in workers exposed to nanomaterials. Int J Mol Sci. 2014;15:878-94.

153. Martin J, Demokritou P, Woskie S, Bello D. Indoor Air Quality in Photocopy Centers, Nanoparticle Exposures at Photocopy Workstations, and the Need for Exposure Controls. Ann Work Expo Health. 2017;61:110-22.

154. Viana M, Fonseca AS, Querol X et al. Workplace exposure and release of ultrafine particles during atmospheric plasma spraying in the ceramic industry. Sci Total Environ. 2017;599-600:2065-73.

155. Song Y, $\mathrm{Li}$ X, Du X. Exposure to nanoparticles is related to pleural effusion, pulmonary fibrosis and granuloma. Eur Respir J. 2009;34:559-67.

156. Scheepers PTJ, Masen-Poos L, van Rooy FGBGJ et al. Pulmonary injury associated with spray of a water-based nano-sized waterproofing product: a case study. J Occup Med Toxicol. 2017;12:33.

157. Li G, Liang L, Yang J et al. Pulmonary hypofunction due to calcium carbonate nanomaterial exposure in occupational workers: a cross-sectional study. Nanotoxicology. 2018;12:571-85.

158. Pelclova D, Barosova H, Kukutschova J et al. Raman microspectroscopy of exhaled breath condensate and urine in workers exposed to fine and nano TiO2 particles: a cross-sectional study. J Breath Res. 2015;9:036008.

159. Pelclova D, Zdimal V, Kacer P et al. Leukotrienes in exhaled breath condensate and fractional exhaled nitric oxide in workers exposed to $\mathrm{TiO} 2$ nanoparticles. J Breath Res. 2016;10:036004

160. Zhao L, Zhu Y, Chen Z et al. Cardiopulmonary effects induced by occupational exposure to titanium dioxide nanoparticles. Nanotoxicology. 2018;12: 169-84.

161. Moitra S, Haldar P. Work-Related Asthma. In: Annesi-Maesano I, editor. Encyclopedia of Respiratory Medicine, 2nd Edition 2020. 